IRSTI 10.09.01

\author{
Useinova K.R. ${ }^{1}$, Bazarbaeva A.T. ${ }^{2}$ \\ ${ }^{1}$ Candidate of Legal Sciences, Acting Associate Professor, Law Faculty,e-mail: karlygash_usein@mail.ru \\ ${ }^{2} 1$ st year Doctoral student (Ph.D. student), Law Faculty \\ al-Farabi Kazakh National University, Kazakhstan, Almaty
}

\title{
ON THE QUESTION OF THE RELATIONSHIP BETWEEN THE INSTITUTIONS OF “BLOOD FEUD” AND “TALION”
}

The article is devoted to the problem of the relationship between the institutions of "blood feud" and "talion". The institution of blood feaud is a universal interdisciplinary institution of the law of the traditional society. Blood rushing, as a custom met at different times in different nations. The article reveals the principles of blood feud. According to the authors of the article, the principle of talion was the basis of blood revenge. Justifying this point of view, the authors note that the blood revenge could cause reciprocal blood revenge and initiate an endless relay race of murders, which could lead to the death of both hostile groups. Necessity was the emergence of some rules governing conflicts between teams. The result was the famous principle, which is known as the talion. In the end, the talion comes to replace the blood feud. It should be noted that the principle of talion is characteristic of almost all legal systems at the initial stage of their development. This principle was known to be the laws of Hammurabi, the laws of 12 tables, Jewish law, medieval German laws, etc. However, fundamental changes in the economic, social life of society, expressed in the division of labor, the development of trade, etc. led to the fact that the talion from an effective regulator of social life turned into its opposite, "into something that disorganizes, destroys society". To overcome the talion, society introduces certain measures, the main purpose of which is to limit the scope of the norms of equal retribution, which ultimately led to the formation of two types of norms: state-legal and moral. Research and analysis of the institutions of blood feud and talion in the traditional nomadic society of the Kazakhs showed that despite the weakness of state power, she was interested in a peaceful resolution of the conflict.

Key words: talion, blood feud, conflict, jurisdiction, Jewish law, medieval German law, revenge.

$$
\begin{aligned}
& \text { Усейнова К.Р. }{ }^{1} \text {, Базарбаева А.Т. }{ }^{2} \\
& \text { 1заң ғылымдарының кандидаты, доцент, e-mail: karlygash_usein@mail.ru } \\
& 21 \text { курс Аокторанты } \\
& \text { әл-Фараби атындағы Қазақ ұлттық университеті, заң факультеті, Қазақстан, Алматы қ. }
\end{aligned}
$$

Мақалада «қан кегі» және «талион» институттары арасындағы өзара қатынас мәселесі талқыланады. Қан кегі институты - дәстүрлі қоғамның құқығының әмбебап пәнаралық институты. Қан кегі әртүрлі елдерде әлет-ғұрыптар кездеседі. Мақалада қан кегі қағилалары ашылады. Мақала авторларының пікірінше, талион қағидаты қан арқылы кек алудың негізі болды. Осы көзқарасқа негізделе отырып, авторлар қан арқылы кек алу қайта қанмен кек қайтаруға және ұжымдағы кісілер өліміне әкеп соғуы мүмкін өлтірудің шексіз эстафетасы іспетті екендігін айтады. Ұжым арасындағы қақтығыстарды реттейтін кейбір ережелердің пайда болуы қажет болды. Нәтижесінде талион деп аталатын танымал қағида пайда болды. Ақыр соңында, қан кегінің орнына талион келді. Айта кету керек, талион қағидасы барлық дерлік құқықтық жүйелердің бастапқы кезеңіндегі дамуына тән. Бұл принцип Хаммурапидің заңдары, 12 кестенің заңдары, еврей құқығы, ортағасырлық неміс заңдары және т.б құқықтық жүйелерде таныс болды. Аегенмен, қоғамның экономикалық, әлеуметтік өміріндегі іргелі өзгерістер, еңбек бөлінісі, сауда-саттықты дамыту және басқалары көрініс тапты, бұл әлеуметтік өмірдің тиімді реттеушісінен түскен талонның керісінше болды, «қоғамды бұзады». Табысты жеңу үшін қоғам белгілі бір шаралар қабылдайды, оның басты мақсаты тең дәрежеде жазалаудың нормаларын 
шектеу болып табылады, нәтижесінде сайып келгенде екі түрлі нормалар: мемлекеттік-құқықтық және адамгершілік. Қазақтардың дәстүрлі көшпелі қоғамында қан айналымы институттарының зерттеуі мен талдауы мемлекеттік биліктің әлсіз болғанына қарамастан, ол жанжалды бейбіт жолмен шешуге мүАделі екендігін көрсетті.

Түйін сөздер:. талион, қан кегі, қақтығыстар, юрисдикция, еврей заңы, ортағасырлық неміс заңы, кек алу.

\section{Усейнова К.Р. ${ }^{1}$, Базарбаева А.Т. ${ }^{2}$}

${ }^{1}$ кандидат юридических наук, доцент юридического факультета, e-mail: karlygash_usein@mail.ru ${ }^{2}$ Аокторант 1-го курса юридического факультета

Казахский национальный университет им. аль-Фараби, Казахстан, г. Алматы

\section{К вопросу о взаимоотношениях институтов «кровная месть» и «талион»}

Статья посвящена проблеме соотношения институтов «кровная месть» и «талион». Институт кровной мести является универсальным межотраслевым институтом права традиционного общества. Кровомщение как обычай встречался в разное время у разных народов. В статье раскрываются принципы кровной мести. По мнению авторов статьи, в основе кровной мести лежал принцип талиона. Обосновывая данную точку зрения, авторы отмечают, что кровная месть могла вызвать ответную кровную месть и положить начало бесконечной эстафете убийств, которая могла привести к гибели обоих враждующих колмективов. Необходимостью стало возникновение каких-то правил, регулирующих конфликты между комлективами. В результате возник знаменитый принцип, который известен под названием та^иона. В конечном итоге на смену кровной мести приходит талион. Необходимо отметить, что принцип талиона характерен практически Аля всех правовых систем в начальной стадии их развития. Аанный принцип был известен законам Хаммурапи, законам 12 таблиц, еврейскому праву, средневековым германским законам и т.А. ОАнако фундаментальные изменения в экономической, социальной жизни общества, выражающиеся в разделении труда, развитии торговли и т.А., привели к тому, что талион из эффективного регулятора общественной жизни превратился в свою противоположность, «в нечто, что дезорганизует, разрушает общество». Чтобы преодолеть талион, общество вводит определенные меры, основной целью которых является ограничение сферы применения норм равного возмездия, что в конечном итоге привело к формированию Авух типов норм: государственно-правовых и моральных. Исследование и анализ институтов кровной мести и талиона в традиционном кочевом обществе казахов показали, что, несмотря на слабость государственной власти, она заинтересована в мирном разрешении конфликта.

Ключевые слова: талион, кровная месть, конфликт, юрисдикция, еврейское право, средневековое немецкое право, месть.

\section{Introduction}

The universal, interdisciplinary institution of the law of traditional society is the institution of blood feud. Blood feud, as a custom could be observed at different times in different nations. As noted in the encyclopedic dictionary F.A. Brockhaus and I.A. Ephron, one of the reasons for the war in year 311 in the Roman Empire of Constantine the Great (b. February $27274 \mathrm{~g}$ ) with Maxentius it served as a revenge to a killer of his father (Brokgauz, 1996). Thus, in some tribes of Australia, committing murder leads to a blood feud that takes on excessive forms, open violent clashes. In the group of tribes from the Arnhemland peninsula who had early contacts with a more developed Muslim civilization, there is controlled revenge, subject to precisely established rules (Berndt, 1981: 264).

The basis of blood feud, in our opinion, was the principle of talion. This is what N.U. Userov writes about this: "In the past, blood feud was not limited at all. Then the principle of talion was established - proportionality of retribution to insult or damage, and even later, revenge was replaced by ransom (kun). In favor of the victim or his close relatives, they began to take ransom (kun) in kind or cattle as ransom (kun). (Userov, 2005: 446) Further, the scientist notes that the kun was distributed equally among all the relatives. This contributed to the deliverance of the kinsmen from the murder, as well as allowing them to defend themselves together. Ultimately, this contributed to the reduction of blood shedding. So, modern researchers on this occasion note the following: "One of the rules" Zhety jargy" - proportionality, adequacy of punishment to the committed crime, i.e. the principle of talion (eye for an eye, blood for blood, life for life) ". (Uzbekov, 1998) The authors of the classic commentary on the Mesopotamian legislative monuments G. Driver and J. Miles in the volume "The Babylonian Laws" 
wrote that the entire punishment system or the Semites was based on the talion, which itself is nothing more than a legitimized restriction of blood revenge (Driver, 1952: 60)

\section{Main part}

Blood revenge could cause reciprocal blood revenge and initiate an endless relay of murders, which could lead to the death of both warring groups. Necessity was the emergence of some rules governing conflicts between teams. The result was the famous principle, which is known as the talioon. It consisted in the fact that the return damage should be equal to the initial damage: "an eye for an eye, a tooth for a tooth", "death for death". In the event that the injured party inflicted equivalent damage to the party initiating the conflict, it was considered exhausted and the hostility was put to an end. Now the injured party had no right to retaliation. If she tried to do this, then a new conflict unfolded, again there was hostility.

Researcher Chepus A.V. notes that "the first rule of blood revenge is the rule of equivalence of the offense caused, i.e. "Equal to equal." And only after the lapse of many centuries will there be a change of blood feud by the principle of "talion", on the basis of which the first attempts will be made to form an institution of responsibility". (Chepus, 2015: 9)

The basis of blood feuds - are the following principles:

- the establishment of victim victims by the members of the family of the offenders "in accordance with the status and virtues of the deceased, and the question of how the person doomed to revenge had to do with the actual murder, in the archaic epoch simply did not interest them" (Maltsev, 2012:137);

- originally blood feuds could spread to any member of the clan, therefore the composition of the avengers and the victims were extremely wide, then later women, children, physically handicapped, including the old people, according to the unspoken rule, could not be victims for realizing their blood feud;

- because "responsibility" was collective, not individual revenge, not for the murderer, but for the clan from which he came, because the man of the ancient society simply could not live outside the collective - clan, tribe, community;

- blood revenge was realized only in cases involving the killing of one member of the gens by another, nor any other crimes in the current sense of the word, but did not fall under the blood revenge;
- about any blood feud could not be talked about within one genus, if one member of the genus killed another, then no actions to kill him were applied to him, but simply expelled from the genus, which indicated that such a man was sentenced to death;

- many members of a clan involved in the conflict and the inability to observe the rules of equivalence led to a delay in the process of blood revenge, i.e. after the act of revenge, the opposite clan found that the loss of the clan was more than relied upon, and accordingly the right to avenge offenders passes to them, because many clans were exterminated altogether;

- it was impossible to exclude the fact of completion of the second blooded revenge conciliation procedures with the participation of other rows.

So, among the peoples of the Caucasus between being in a state of blood feud, reconciliation and ransom for blood was possible in the following cases:

- when the killing is done not because of enmity and intentionally, but by chance;

- If the killer instead of one person mistakenly killed another;

- If the killer intentionally accomplished encroachment personal injury;

- if blood was shed among namesakes;

- when the blood revenge occurs not from the avenger, but by the person who was bribed by the avenger, and the bribed person will kill the victim (Diasabidze, 1974).

As for the talion, in Latin, it means retribution. Researcher Rudenko A.M. states that " talion " means "a form of social regulation corresponding to a rather early stage of development of human communities ". One cannot but agree with the author, who asserts that " talion is the limiter of blood revenge on the principle: retribution must strictly correspond to the damage ... Talion as a punishment demanded several lives for one killed person, and life for life. This moral law was the undisputed duty of the men of the tribe. His performance was an honor to them. Taleon really was a priority rule in the early stages of development, because it was a mechanism for restricting individual arbitrariness, curbing revenge from the barbarity and aggressiveness of a person.". (Rudenko, 2017)

As noted by R.G. Apresian, "the right of the talion is generally known to us from the Pentateuch. In its most expanded form, it is contained in the Book of Exodus (21: 12-37), and its key formula is this: "... and if there is any harm, give soul to the soul, eye to eye, tooth to tooth, hand to hand, foot by foot, burn for burning, wound for wound, bruise for bruise "(Ex.21: 24-26). In the later moral phi- 
losophy, analysis of the talion is carried out taking into account the refined-generalized its formulation, in which the principle of reversible equality is expressed quite clearly" (Apresyan, 2002: 245)

In the book of Genesis, this is expressed in a more generalized way: "Whoever sheds human blood, said the Lord, blood will be shed by the hand of man."

The principle of talion is mentioned in such a code, which is called "Esim Khannah Eski Zholy". In particular, in the fourth part, the following is written: "Qanǵa qan, janǵa jan». «Iaǵn1 óltirse óltirý, qolyn syndyrsa syndyrý, kózin shyǵarsa kózin shyǵarý. Adam shekten tys auýandyqpen óltirilse,eki jaq kelispese bul qaǵida júzege asyrylady». (Esim hannyn eski Zhol, 2005: 147)

It should be noted that the principle of talion is characteristic of almost all legal systems at the initial stage of their development. Famous English scientist A.R.Radcliffe - Brown writes about this as follows: "The injured group is believed to have grounds for revenge, and the group members are often obliged to avenge the victim. The action of retribution is governed by custom: lex talionis (the law of talion - equal retribution) requires that the damage inflicted be equal to the inflicted damage". (Edcliffe, 2001: 248)

This principle was also known by the laws of Hammurabi, the laws of 12 tables, Jewish law, medieval German laws, etc. Characteristically, the use of the talion Hammurabi significantly expanded compared with previous times, and the practice of monetary refunds, on the contrary, sharply reduced, guided by their ideas of justice, partly inherited from the nomadic ancestors, and partly dictated by the desire not to give the rich advantages over the poor.

The laws of Hammurabi give the most vivid idea of the types of talion. A typical (simple) talion was defined by the formula " equal for equal": for a tooth knocked out, one should knock out a tooth from the culprit, etc. (article 196,197,200) (Sadikova, 2002:26)

The symbolic talion ordered to cut off the part of the body with which the criminal acted against people: for an unsuccessfully performed operation, the doctor cut off the fingers, etc. (article 192,195,218,226). The least common in the laws of Hammurabi is the mirror form of the talion, which VG Grafsky rightly calls objective imputation (liability without fault ) (Grafsky, 2000: 69) At the mirror talion, children were responsible for the crime committed by the father, if the victim's children were killed as a result of it (art. 210,230) (Sadikova, 2002: 27-28) The existence of a talion punishment system may be due to the desire to limit the advantage of the rich over the poor.

The principle of the talion was especially vividly manifested among the Caucasian peoples. The reason for the blood feud was killing, wounding, kidnapping a girl, seizing the land, insulting a guest, honor, a home hearth that was venerated by the highlanders, etc.

Thus, revenge in the Adyg society was a social institution whose main goal was to resolve the conflict. Especially, in our opinion, it should be noted that the choice of the form of conflict settlement depended on many factors, but two things played a crucial role - personal and social. However, unlike other peoples of the Caucasus, among the Circassians in the second half of the XIX century, revenge ceases to be a duty. It is beginning to be considered as a right that can be used or not used.

In Dagestan, according to A.V. Komarov, (Zadvornov, Daubekov, 2000: 25) adats in the late XIX - early XX centuries. allowed to kill their blood enemy, the attacker robber, caught at the crime scene, the thief, the thief of a woman. The right and the obligation to pursue the killer or to come to terms with him, as a rule, belonged to the closest relative of the victim. Reconciliation could take place no sooner than a year after the crime, and all this time the killer had to be in exile and hide from vengeance. Blood revenge was a duty and a matter of honor for all members of the genus of the victim, there were cases when it stopped - in the case of no reconciliation - only after the complete destruction of one of the warring families. In the pre-revolutionary literature, there is a paradoxical example when, in accordance with the adats in one of the Dagestan villages, blood rush between two genera - tokhums lasted for more than 200 years, and it began in a row over a chicken.

Traveled through the North Caucasus in 17811783. Quartermaster in the Russian service, Shteder wrote about the Ossetians' blood feud: "Bloody revenge and unauthorized actions were obligatory among families; shame and contempt continued until this duty was fulfilled. Vengeance, robbery and murder were considered a virtue, and as a result, it was glorious to die.". (Zadvornov, Daubekov, 2000: 26)

Basically, among the Caucasian peoples, revenge existed in two forms: blood and nonblood. The basis of this distinction was the nature of the initial conflict. If blood was shed as a result of the initial conflict, the relationship between the parties to the conflict and the relatives of the victim was considered as blood. In the event that the cause 
of the initial conflict was the infliction of property damage, the relationship was considered hostile, i.e. necro. In this case, the amount of damage was not taken into account. It should be noted that for Ossetians, the infliction of property damage could have caused not only hostile relations, but also blood feud, during which the victim could take revenge for the theft of livestock.

Most of the peoples of the North Caucasus had a certain order of vengeance. Thus, the Chechens decided to take revenge on the council of elders. The choice of the subject of revenge, i.e. people who were supposed to commit it and an object of revenge, i.e. the person to whom it could be directed, as a rule, depended on two factors: first, on the nature of the initial conflict; second, the degree of damage. In contrast to the Kazakh customary law, only victims could be subject to revenge for cattle thefts in Caucasian society. They, as a rule, did not resort to the help of relatives.

In this way, of production recently consanguinity universal for companies at the stage of the tribal system and the preservation of its residual effects, he wrote about a major ethnographer kavkazoved MO Indirect : "Care of self-preservation forces the whole race to stand up for protection, even if only one of the members of the race was offended. Revenge becomes a duty, a matter of honor, a sacred duty ". (Kosven, 1953: 57)

Taleon wore a group character and any member of the tribal community, a single family or the genus as a whole could be the object of reciprocal revenge (Sarsenbayev, 1974: 27)

The wide and rapid development of property relations led to the emergence of more civilized forms of the talion, providing for the right to pay off committed crimes by fixed material means. (Indirect, 1925:25)

According to A. Kaliev, the true meaning of this principle was to "authorize damage equal to damage and thereby maintain a balance between births" (Kaliev, 2004:328)

Like any other method of social regulation, the talion has a number of features that are unique to him. "Firstly, in the talion there is no clear distinction between external objective and internal psychological motivations for action, which are passive and reciprocal.The point is to restore the imbalance, that is, the main criterion for determining punishment is sameness, the so-called status quo. However, the requirement of punishment, which was supposed to be an exact copy of the action - a type, was often not carried out for purely physical reasons.
Secondly, in the talion it is impossible to dismember group (clan) and individual interest, since they are merged. Taleon focuses both interests, being at the same time a fact of both individual and public consciousness.

Thirdly, the norms of equal retribution do not correlate with the personality of the offender or his intentions; they deal only with actions. More precisely, in the talion is not taken into account the specific human individuality. The main role is played by the abuser belonging to a specific clan collective. But since the individual and the race are merged in an undifferentiated unity, hence the conclusion - that the person is still judging the person ". (Alekseeva, 1986: 328)

A.A. Huseynov characterizes the talion as follows. "First of all, the scale of the action regulated by the talion lies outside the actor, it is set from the outside; the reciprocal action must be equal to the perfect injustice. Secondly, the value basis of the action performed on the basis of a talion is the formal equivalence of retribution; the logic (and psychology) of the talion does not imply the division of actions into good and bad, as well as those responsible for which lies on the individual, and those for which the community is responsible. Thirdly, in retaliation, taken by the standards of the talion, only the passed act is taken into account - intentions and particular circumstances (possibly not dependent on the actor) are not taken into account". According to the author, this is "a description of the most archaic version of the talion". However, in practice, we observe that with the development of society, the talion undergoes certain changes, "and the vector of these changes is directed towards more and more easing of the talion's sanctions".

\section{Conclusion}

Given the above, we can formulate the following conclusions: Firstly, talion is a rule governing proactive actions. Secondly, the principle of talion is based on the desire for justice. Thus, with the birth and development of the talion principle, the concept of justice begins to take shape. When one side by its actions damages the other side, it means that justice is violated in the first place. Naturally the injured party is trying to restore this justice. To this end, it causes adequate damage. Thirdly, the talion is nothing more than the first way to restore the violated right. Fourth, the essence of the principle of retaliation is to apply a responsen damage equal to the initial. The main thing in it is proportionality, that is, in this way the talion limits the 
measure of retribution. It can manifest itself as the principle "an eye for an eye," "ear for ear," "blood for blood," "hoof for hoof." Therefore, in our opinion, the principle of " ққlаққа-құlaқ, tұуаққаtұуақ" is a manifestation of the principle of talion. Fifth, "the very fact of its existence threatens the talion, and its main sanction is in danger". (Alekseeva, 1986: 352) Sixthly, "the standard of action assumed by the talion is situational in its applica- tion, however, as a principle of action, it is supersubjective and universal". Seventh, the talion wore a group character on both sides of the conflict. The object of reciprocal revenge could be both the clan and the family as a whole, and any of the opposite kind In our opinion, the main thing in the talion is the desire to establish a balance by recompensing the deserving person, justly, an objective desire to achieve justice (Useinova, 2007: 68).

\section{References}

Apresyan R.G. On the treatise of Hugo Grotius "On the law of war and peace" // Ethics Sector of the Institute of Philosophy RAS. Ethical thought. - M., 2002. - Vol. 3. - p. 245-263.

Berndt, R.M., Berndt, K.H. World first Australians: Trans. from English, 1981. - $447 \mathrm{~s}$.

Brokgauz F.A., Efron I.A. Encyclopedic dictionary. - 1996. - 5547.

Chepus A.V. The Institute of Blood Vengeance, as the primary element in the formation of responsibility in antiquity // Proceedings of the international scientific-practical conference: Main problems and development trends in modern jurisprudence - Volgograd, 2015. - P. 9-11.

Diasabidze G.I. Murder because of the blood feud of the Soviet criminal law: Based on the Adjarian SSR: diss ... c.l.s. - Sverdlovsk, 1974. - $167 \mathrm{p}$

Driver G.R, Miles JC The Babylonian Laws. Vol. one. Legal Commentary. - Oxford, 1952.

Edcliffe P. - Brown A.R. Structure and function in a primitive society: Essays theory and lectures. - M., 2001. -304 p.

Есим ханнын ески жолы // Древний мир казахского права. - Алматы, 2005. - Т. 4. - С. 145-152.

Графский В.Г. Общая история права и государства: Учебник для вузов. - М., 2000. - С. 752.

Косвенный М. Преступление и наказание в предгосударственном обществе. - М. - Л., 1925. - 140 с.

Калиев А. Особенности защиты в судебной системе Казахстана XYIII-XIX вв. // Древний мир прав казахов. - Алматы, 2004. - Вып. 2. - С. 327-331.

Косвен М.О. Очерки по истории первобытной культуры. - М., 1953. - 239 с.

История первобытного общества: эпоха первобытно-племенного сообщества / Под ред. В.П. Алексеева А.И. Перщиц. - М., 1986. - 359 c.

Мальцев Г.В. Месть и возмездие в древнем законе. - М., 2012. - 736 с.

Чтения по всеобщей истории государства и права. / Под ред. Садыкова В.Н. - М., 2002.

Руденко А.М. Этика: учебное пособие - М., 2017. - 228 с.

Сарсенбаев Н.С. Обычай, традиция и общественная жизнь. - Алма-Ата, 1974. - 180 с.

Усеинова К. В. Институт Баримты и его место в общепринятой правовой системе Казахстана: дисс ... к.ю.н. - Алматы, 2007. $-113 \mathrm{c}$. 453.

Усеров Н. Структура и содержание «Жеты Жарги» // Древний мир казахских прав. - Алматы, 2005. - Вып. 4. - С. 430-

Узбеков С., Хан Тауке и Правовой консультативный совет Жеты Жарги. - Алматы, 1998. - С. 88.

Задворнов М., Даубеков А. Обычай кровной мести в перспективе отечественного уголовного права // Уголовное право. 2010. - №4. - п. 24-28.

\section{References}

Apresyan R.G. On the treatise of Hugo Grotius "On the law of war and peace" // Ethics Sector of the Institute of Philosophy RAS. Ethical thought. - M., 2002. - Vol . 3. - p. 245-263.

Berndt , R.M., Berndt , K.H. World first Australians / Trans. from English, 1981. - 447 s.

Brokgauz F.A., Efron I.A. (1996) Encyclopedic dictionary. - 5547

Chepus A.V. The Institute of Blood Vengeance, as the primary element in the formation of responsibility in antiquity // Proceedings of the international scientific-practical conference: Main problems and development trends in modern jurisprudence - Volgograd, 2015 - P.9-11

Diasabidze G.I. (1974) Murder because of the blood feud of the Soviet criminal law: Based on the Adjarian SSR: diss ... k. yu.n . - Sverdlovsk. -167 p.

Driver G.R, Miles JC The Babylonian Laws. Vol. one. Legal Commentary . - Oxford , 1952

Edcliffe P. - Brown A.R. Structure and function in a primitive society: Essays theory and lectures. - M., 2001. - 304 p.

Esim hannyn eski Zholy / / The ancient world of Kazakh law. - Almaty, 2005. - T.4. - 145-152 bb.

Esim hannyn eski zholy // Drevnij mir kazahskogo prava. - Almaty, 2005. - T.4. - C.145-152

Grafskij V.G. Obshhaja istorija prava i gosudarstva: Uchebnik dlja vuzov. - M., 2000. - c.752 
Kosvennyj M. Prestuplenie i nakazanie v predgosudarstvennom obshhestve. M. - L., 1925. - 140 s.

Kaliev A. Osobennosti zashhity v sudebnoj sisteme Kazahstana XYIII-XIX vv. // Drevnij mir prav kazahov. - Almaty, 2004. - Vyp. 2. - s. 327-331

Kosven M.O. Ocherki po istorii pervobytnoj kul'tury. - M., 1953. - 239 s.

Istorija pervobytnogo obshhestva: jepoha pervobytno-plemennogo soobshhestva / Pod red. V.P. Alekseeva A.I. Pershhic. - M., 1986. $-359 \mathrm{~s}$.

Mal'cev G.V. (2012) Mest' i vozmezdie v drevnem zakone. - M. - 736 s.

Chtenija po vseobshhej istorii gosudarstva i prava. / Pod red. Sadykova V.N. - M., 2002

Rudenko A.M. (2017) Jetika: uchebnoe posobie - M. - 228 s.

Sarsenbaev N.S. (1974) Obychaj, tradicija i obshhestvennaja zhizn'. - Alma-Ata. - 180 s.

Useinova K. V. (2007) Institut Barimty i ego mesto v obshheprinjatoj pravovoj sisteme Kazahstana: diss ... k.ju.n. - Almaty. $113 \mathrm{~s}$.

Userov N. Struktura i soderzhanie «Zhety-Zhargi» // Drevnij mir kazahskih prav - Almaty, 2005. - Vyp. 4. - str. 430-453.

Uzbekov S., (1998) Han Tauke i Pravovoj konsul'tativnyj sovet Zhety-Zhargi. - Almaty. - c.88

Zadvornov M., Daubekov A. Obychaj krovnoj mesti v perspektive otechestvennogo ugolovnogo prava // Ugolovnoe pravo. 2010. - №4. - p. 24-28 